\title{
AANTEEKENINGEN OP EEN OUDEN MALEISCHEN RAMAJANA-TEKST.
}

\author{
DOOR \\ Dr. PH. S. VAN RONKEL.
}

Van het begin der $17^{\mathrm{e}}$ eeuw dateeren de oudst-bekende Maleische handschriften, waarin de taal haren vorm, die enkele eeuwen lang zoude nagevolgd worden in en vooral buiten het Maleische stamland, reeds geheel en al had verkregen. Oudere litteratuur is onbekend; immers de weinige volzinnen in inscripties behooren niet tot de litteratuur, en leeren ons buitendien niets ten opzichte van de geschiedenis der taal. Reeds in den tijd der opschriften, met name van het $21^{\text {e }}$ regelige van Pagaroejoeng (Oudh. Verslag 1912, Bijl. H.) schijnt het Maleische idioom als schrijftaal morphologisch hetzelfde geweest te zijn als thans.

Van onderscheid tusschen ouden en nieuwen taalvoorm is nagenoeg geen sprake, hoogstens kan men gewagen van ouder Maleisch, in dien zin dat de oudst bekende teksten in woordenkeus en woordvorm enkele eigenaardigheden hebben, die de latere taal niet vertoont. Inderdaad zijn in de oudste handschriften enkele woorden aangetroffen, die de latere litteratuur niet kent, en eenige taalkundige bijzonderheden opgemerkt die later niet meer voorkomen, of als zoogenaamde uitzonderingen voortleven. Een voorbeeld is het verdwijnen, tegen den regel in, van mediaebeginklanken in den nasaal, welk verschijnsel, in de oudere geschriften als de Cambridge-manuscripten (Bijdragen 6, II, 1-53) en de werken van Noeroeddin Djilani al-Raniri, vooral de Șirât al-moestakịm, bijna algemeen, in de latere taal in een paar "uitzonderingen» als menengar van dengar en memoenoeh van boenoeh voortbestaat.

Of dit feit duidt op een ouderen toestand der taal, valt niet met zekerheid uit te maken, daar ook gewestelijk verschil in het uitgestrekte taalgebied tot het gebruik van die vormen kan 
aanleiding gegeven hebben. Hoe het zij, aan de oudere geschriften, om de teksten uit het begin der $17^{\mathrm{e}}$ eeuw zoo te noemen, is een tot zekere hoogte eigen karakter in taalvorm en woordgebruik niet te ontzeggen, terwijl de spelling in die schrifturen kan gezegd worden van de latere systemen belangrijk te verschillen.

Wanneer zulk een oudere tekst toegankelijk gemaakt wordt, is het dus zaak al wat daarin van de huidige taalvormen afwijkt te noteeren, niet zoozeer om de betrekkelijk geringe beteekenis der eigenaardigheden van één tekst, als wel ter vermeerdering van het luttele vergelijkingsmateriaal. Één handschrift te nemen als grondslag van lexicografische of taalhistorische nova is en blijft een gevaarlijk werk, doch als poging tot het aanbrengen van wat meer geschiedkundige materie dan wij tot nog toe bezitten, kan het publiceeren van aanteekeningen op zulk een manuscript, ook al moest het zonder bijtekst gebruikt worden, van eenig nut zijn.

De bedoelde tekst nu is de Maleische Seri Rama, de - zooals blijken zal - niet-primaire versie van het Sanskrit-Râmâyaṇa. In Marsden's Malayan Grammar zijn épisodes uit den Rama afgedrukt, en in 1843 is een nagenoeg volledige uitgave bewerkt door Roorda van Eysinga. In $N^{\circ} 31$ van den Straits-Branch der Royal Asiatic Society is indertijd het een en ander medegedeeld over een oud handschrift van het verhaal in de Bodleian Library, dat in den in 1910 verschenen catalogus van Greentree en Nicholson uitvoerig is beschreven. Dit Manuscript, in 1633 door een Engelschen aartsbisschop gekocht, behoort als dateerende uit het begin der $17^{\mathrm{e}}$ eeuw, tot de "oude teksten", en is in No 71 (Dec. 1915) van genoemd tijdschrift geheel uitgegeven "as closely as can be done by letterpress printing".

Voor de geschiedenis der Maleische spelling is zulk eene uitgave ongetwijfeld van belang, doch dit punt maakt geen onderwerp van bespreking voor ons uit, zoodat wij kunnen volstaan met te zeggen dat in dit geschrift de oudere methode van spaarzaamheid in klinkeraanduiding door zgn. verlengingsletters tot het uiterste, bijkans over de grens, der leesbaarheid gaat.

In $\mathrm{N}^{\circ} 70$ (April (1917) van meergenoemd tijdschrift geeft W. J. Shellabear eene vergelijking tusschen den inhoud van het Sanskrit-dichtwerk en dien der Maleische versie, welke ‘brief summary of the Ramayana of Valmiki», en "analysis of the Malay 
Hikayat Sri Rama» met de vele noten, een nuttig overzicht van litteraire paralellen mag genoemd worden, ook al brenyt het ons voor de kennis der geschiedenis der migratie van het Râmâyaṇạ naar het Oosten niet verder,

De tekst nu beslaat 284 bladzijden van 25 regels zeer kleinen druk. Een groote tekst inderdaad, die echter weinig stof voor taalkundige opmerkingen levert, niet alleen omdat de materie eenvormig is, maar ook omdat het ontbreken van vergelijkingsmateriaal ons huiverig maakt voor het nemen van conclusies. Doch, hoe weinig in aantal ook, ter vermeerdering van de beperkte reeks van vaststaande feiten uit oudere taal, kunnen de aanteekeningen op den Oxfordschen Rama-tekst wellicht van eenig nut zijn,

Evenals in de Cambridge-handschriften en in geschriften van Al-Raniri treft ons ook in dezen Rama de tegen den regel in plaats vindende oplossing van beginmediae in den neusklank van het voorvoegsel me. Zoo memitjara van bitjara (bl. 10:5), menjoendjoengkan van djoendjoeng (bl. $119: 11$ v. o.), memongkar van bongkar (bl. 141:10 v.o.), memoeka van boeka (bl. 169:11 v. o.), maar op diezelfde bladzijde op r. 7 v. o, en 6 v. o. memboeka.

In de Maleische spraakkunsten worden gewoonlijk acht woorden genoemd, die in den vorm op i een voorvoegsel ke verkrijgen; in enkele handschriften wordt wel eens een andere i-vorm op die wijze behandeld, hier noteeren wij dikesopaninja $(11: 6,29: 10$ v. o.) en kita kesopani (125:8). In den trant van pengelihatan (waarvan Van der Tuuk indertijd aanwees, dat het zóó en niet penglihatan kan zijn, daar vóór de 1 de nasaal geen stand houdt) treft men hier aan pengedengaran, in den zin pengelihatan mana engkau [1ihat] dan pengedengaran mana engkau dengar.

Eigenaardige woorden zijn - met de ten aanzien van één enkel handschrift altijd gebodene voorzichtigheid - nu en dan op te merken; zoo het door Ch. A. van Ophuysen (Bijdragen $66: 217)$ aangewezen woord nagara (-goenoeng), bl. $120: 2$, d. i. het Sanskrit nâga + agra, en het in de woordenboeken niet vermelde, allicht voor Minangkabausch gehoudene, doch in Van Ophuysen's glossarium op zijn leesboek voorkomende gantih = spinnen $(120: 4)$.

Eigenaardige nasaleering schijnt aanwezig in mamangkoe 
= mamakkoe, (bl. $11: 1)$, en hatingkoe= hatikoe (12:3). Als de lezing, bl. 2:9, menghalkan dirinja juist is, en de beteekenis daarvan kan zijn: zich gedragen in bepaalde omstandigheden, zou deze vorm een van elders nog niet bekende term kunnen zijn. Het wel van elders bekende op Javaansche wijze gevormde $\mathrm{ngapa}=$ mengapa komt hier telkens voor $(3: 6,25: 2,185: 0:$ v. o., $265: 3$ v. o. enz.); naast het Javaansche kenapa $(165: 4$ v. o., $170: 9,173: 11,265: 12$ v. o. $)$ valt het analytische kena apa (262:2 v. o.) op. Telkenmale, na bl. $40: 4$ treedt in plaats van seperti de vorm perti op, dat het Sanskrit prati kan zijn, versterkt met se, evenals sene(n)tias a $=$ Skrt. nityacas. Het woord soedah wordt nagenoeg overal geschreven met het verdubbelingsteeken op de $d$, wat wijst op de uitspraak sedah. Als hieruit mag afgeleid worden, dat vroeger het woord sedah luidde - uit dezen tekst alleen daartoe te concludeeren is niet ongevaarlijk - zoude de nog steeds in zwang zijnde spelling zonder wau, die uit etymologische gronden niet te verklaren is, mede daarop kunnen dulden; de verwantschap met telah zoude dan waarschijnlijk zijn. Hier zoude evenals in djeka (blijkens Minangkabausch djåkå) dat in het schrift steeds naar die uitspraak wordt gespeld, de toonlooze e tot voller klank geworden zijn, djeka-djika, sedahsoedah. Ter bevestiging mag de vorm menjedahkan, geschreven menjeddahkan (211:4) aangehaald worden, maar vermeld móet worden dat de schrijfwijze met wa u (133:9 v.o.) als storende uitzondering den regel weder aan het wankelen brengt. Eenige onzekere of slechts éénmaal voorkomende vormen vermelden wij niet; slechts tot het bovenbehandelde beperkt zich wat wij meenden te kunnen aanbieden als aanteekeningen op de nieuwe Rama-uitgave.

Ten slotte iets over den vorm van dit Rama-verhaal! Dat dit Hindoesche litteratuurproduct door eenen moslim in het Maleisch is bewerkt, getuigt de Mohammedaansche kleur:

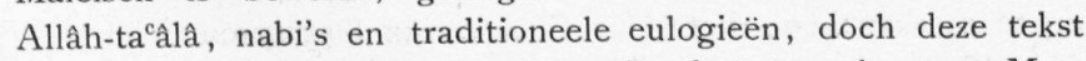
draagt sporen van eene correctuur die de toepassing van Moslimsche namen op heidensche goden niet gedoogde, in den vorm van het doorschrappen van Allah's naam en het vervangen daarvan door dewata, en similarly Allah subha ${ }^{\mathrm{c}} \mathrm{nahu}$ wa taala in many places» (Noot op bl. 1).

Het vraagstuk van de herkomst der Maleische versie wordt 
door dezen tekst eenigszins vergemakkelijkt. Aan onmiddellijke ontleening der Maleische bewerking uit het Sanskrit kan niet gedacht worden; dat zij aan Zuid-Indische bronnen ontleend is valt af te leiden uit de aloude Dekhan-strooming van Hindoeisme en Mohammedanisme, ook van litteratuurproducten, naar den Indischen archipel, en buitendien uit enkele kleine kenteekenen in vormen van namen.

Reeds vroeger (Bijdragen 6, VI, 66) wees Dr. H. H. Jụynboll er op, dat de Hikajat Seri Rama van Tamil oorsprong zoude kunnen zijn, en dat wel op grond van enkele eigennamen, welker vorm naar hij vermoedde gedrâvidiseerd Sanskrit was. Op dit punt geeft de Oxford-tekst meer aanwijzingen dan de uitgave van 1843. Overal toch komen mannelijke eigennamen op an voor, welke uitgang niets anders dan de Tamil-mascul. terminatie a n kan zijn. De uitgang am van levenlooze voorwerpen is zichtbaar bv. in tandaparvadam (178:7) waarin de tenuis tusschen de twee klinkers van het Sanskritwoord parvata naar de verschte Tamil-klankwet is vervormd, in terisoelam $(215: 1)=$ Skrt. triçûla e. d.

Dit weinige duidt reeds op het Tamoelische karakter van de Rama-redactie, die werd vertaald in het Maleisch en in het Javaansch, in welke taal de naam Rama Keling nog steeds aan de herkomst der bewerking herinnert.

Aanwijzingen aangaande vertaler of bewerker geeft onze tekst niet. Trouwens het voorbeeld van Al-Raniri met zijne vele Maleische werken (vermeld door Van der Tuuk in Bijdragen, 3. I, 462 en volg.), en ${ }^{\mathrm{c}}$ Abdoellah Bin ${ }^{\mathrm{c}}$ Abdoelkadir Moensji met zijne Pañcatantra-bewerking wijst er op, dat dergelijk vertaal- of imiteerwerk werd verricht door een Voor-Indiër die Maleisch kende, òf door een niet ras-echten, peranakan-Maleier die - door afkomst of omgang - met eene Hindoestansche taal, hetzij Hindoestânî hetzij Tamil, eenigermate bekend was. 